Original

\title{
Degradation of the Seaweed Wakame (Undaria pinnatifida) by a Composting Process with the Inoculation of Bacillus sp. HR6
}

\author{
JING-CHUN TANG ${ }^{1,2}$, JIAN-HE WEI ${ }^{1}$, KENJI MAEDA $^{3}$, HIROSHI KAWAI $^{4}$, \\ QIXING ZHOU ${ }^{2}$, SHOKO HOSOI-TANABE ${ }^{1}$, AND SHINICHI NAGATA ${ }^{1 *}$ \\ 'Environmental Biochemistry Division, Research Center for Inland Seas, Kobe University, \\ Fukae, Higashinada, Kobe 658-0022, Japan \\ ${ }^{2}$ College of Environmental Science and Engineering, Nankai University, Tianjin 300071, China \\ ${ }^{3}$ Sanyo Techno Co. Ltd., 1504-4, Shinobe, Befu-cho, Kakogawa 675-0131, Japan \\ ${ }^{4}$ Marine Biodiversity Group, Research Center for Inland Seas, Kobe University, \\ Rokkodai, Kobe 657-8501, Japan
}

Received 16 October, 2006/Accepted 5 February, 2007

\begin{abstract}
Disposal of the seaweed wakame (Undaria pinnatifida) by inoculating the halotolerant bacterium Bacillus sp. HR6 was examined in an experimental scale composting system. Strain HR6 was effective in initiating the composting process of wakame, and there was a rapid increase in temperature to over $54.9-55.7^{\circ} \mathrm{C}$ after $18-20 \mathrm{~h}$. The composting process of wakame could be carried out despite a high $\mathrm{NaCl}$ content, $28.2 \mathrm{mg} / \mathrm{g}$, although lower salinity resulted in a shorter lag time and higher weight reduction. In a larger scale composting process with aeration, two peaks of temperature change were found which corresponded well to oxygen consumption and $\mathrm{CO}_{2}$ emission during the process. The $\mathrm{pH}$ increased to 8.83 and organic materials were reduced to $93.4 \%$ after $72 \mathrm{~h}$. The initial $\mathrm{N}$ and $\mathrm{C}$ contents were 3.9 and $34.0 \%$, respectively, both of which decreased during the composting process. The changes in the viable cell numbers suggested that strain HR6 predominated before $24 \mathrm{~h}$ and other microorganisms including HR6 were present in a mixed state during the later period of composting. The total content of alginate (TA), $32.2 \%$ in the initial stage, decreased to $29.2 \%$ after $72 \mathrm{~h}$, while water soluble alginate (WSA) increased, indicating that the solubilization and decomposition of alginate had occurred during the composting process.
\end{abstract}

Key words : Bacillus sp. HR6/Biodegradation/Composting/Wakame (Undaria pinnatifida)/Alginate.

\section{INTRODUCTION}

At present, pollution from various industries has become one of the most serious problems of concern in the Japan Inland Sea area. Reduction of excess organic pollutants, especially $N$ and $P$, in the sea water is important and fundamental for improving the environmental quality of the Inland Sea. Seaweed planting

*Corresponding author. Tel : +81-78-431-6342, Fax : +8178-431-6342. is one of the options where N, P and other pollutants in the water can be accumulated into the body of the seaweed and then the sea water can be cleaned. The brown seaweed Undaria pinnatifida (or "wakame" in Japanese) has been commonly used because this kind of seaweed has a large body and can grow quickly in fertile sea water. Ammonium, nitrate and phosphate in the sea water can be taken up by wakame effectively (Torres et al., 2004), and especially the $\mathrm{N}$ content in the sea water is a limiting factor for the growth of Undaria pinnatifida (Campbell et al., 
1999). The harvested seaweed has become a kind of waste that needs to be disposed of. Usually, wakame is edible, but the harvested wakame in this research may contain pollutants such as heavy metals as well as some toxic chemicals, and thus can not be used as food. In addition, a large amount of seaweeds including wakame which also drift along to the seashore in the eutrophic area in the Inland Sea must be disposed as waste. Thus, the disposal of wakame is important for cleaning the Inland Sea area.

The high water and salt content in wakame makes it unsuitable for incineration disposal. From the viewpoints of economy, technology and environmental protection, composting is one of the best ways to dispose of the seaweed waste (Eyras et al., 1998). Seaweed has been used as fertilizer from ancient time because it contains not only $\mathrm{N}$ or $\mathrm{P}$ but also minerals such as $\mathrm{Ca}^{2+}, \mathrm{Mg}^{2+}$ and $\mathrm{B}$ which promote the growth of crops. Since the heavy metal content of wakame is at a safe level for application in agriculture, it is meaningful that the organic pollutants in seaweed are decomposed during the composting process. The high salt content in seaweed can be washed out by fresh water before composting or the seaweed compost can be mixed with other fertilizer to avoid the adverse effect of high seaweed salt content on the crops. Thus the compost product from the seaweed can be safely reused as fertilizer in the farmland near the seashore, which is important for the recycling of C, N and P (Vendrame and Moore, 2005).

Seaweed composting, however, has little been studied and there are some problems that should be solved before the resulting compost can be used in agriculture (Eyras et al., 1998). In the organic composition of wakame, the contents of protein and carbohydrate are relatively high, indicating that there exist enough organic compounds for microbial growth. However, the carbohydrates consist mainly food fibers such as cellulose, hemicellulose and alginate which are not easily degraded by microorganisms (Yamada, 2001). The high content of alginate is a special characteristic of Undaria pinnatifida with a value of over $50 \%$ of alginate in dry weight
(Skriptsova et al., 2004), which may be the reason for the slow rate of microbial degradation of wakame by composting. In addition, the salt content is $1.5 \%$ and $16.8 \%$ in fresh and dry wakame, respectively (Yamada, 2001). If the water content is adjusted to $70 \%$ during the composting process of wakame, the salt content in the compost will be about $5 \%$, which is approximately 2 -fold higher than the usual content of seawater. No one has yet studied the composting of seaweed with such high salt content.

Usually, composting can be conducted successfully in nature. In some cases, however, inoculation of effective bacteria is required for the rapid disposal of the wastes. In our previous study, an effective bacterium, Bacillus sp. HR6, was isolated from soil and has been used to dispose of food wastes (Mimura et al., 1995; 1999a) and Blue Mussel wastes (Maeda et al., 2003). Strain HR6 may grow in a wide range of $\mathrm{pH}$ (5.7-8.5), temperature $\left(20-50^{\circ} \mathrm{C}\right)$ and salinity $(10 \%$ $\mathrm{NaCl}$ ) (Mimura et al., 1999b). This suggested that strain HR6 can be possibly used to dispose of wakame waste. The purpose of this research is to characterize the properties of the wakame composting process and examine the effect of inoculating strain HR6. Composting of wakame under different conditions using strain HR6 was characterized and the change in physico-chemical and microbial properties was traced for a better understanding of the seaweed composting process.

\section{MATERIALS AND METHODS}

\section{Wakame as the material}

Dried wakame was obtained from the experimental site of the Research Center for the Inland Seas, Kobe University, Awaji City, Kobe, Japan and used as the material in the present experiment. Dried wakame was first washed with fresh water at a ratio of about $20 \mathrm{~L}$ water for $1 \mathrm{~kg}$ dry wakame and then dried again under sunlight, since its salt content was very high. Both dried and washed wakame was cut into pieces of less than $1 \mathrm{~cm}$ with a juice mixer (Matsuden, MJ700. Japan). Table 1 shows the chemical composi-

TABLE 1. Chemical composition of the wakame used for the experiment.

\begin{tabular}{lccccc}
\hline & Water $(\%)$ & $\mathrm{N}(\%)$ & $\mathrm{C}(\%)$ & $\mathrm{C} / \mathrm{N}$ & $\mathrm{NaCl}(\mathrm{mg} / \mathrm{g})$ \\
\hline Dried wakame & 8.22 & 3.64 & 29.82 & 8.19 & 89.0 \\
Washed wakame & 13.72 & 4.14 & 36.95 & 8.92 & 46.2 \\
\hline
\end{tabular}

Dried wakame was obtained by drying the wakame directly under sunlight, while washed wakame was obtained by cleaning the dried wakame using fresh water and then drying it under sunlight. The water content was analyzed by measuring the weight changes after drying the sample in an oven at $105^{\circ} \mathrm{C}$ for $24 \mathrm{~h}$. $\mathrm{N}$ and $\mathrm{C}$ contents were then analyzed using dried samples with NA 2100 Protein Nitrogen analyzer. 
tion of the dried and washed wakame. The nitrogen content was $3.64 \%$ and $4.14 \%$ in the dried and washed wakame, respectively, and higher $\mathrm{N}$ and $\mathrm{C}$ contents were detected in the washed wakame than in the dried type. The $\mathrm{NaCl}$ content was $89.0 \mathrm{mg} / \mathrm{g}$ in the dried wakame and decreased to $46.2 \mathrm{mg} / \mathrm{g}$ in the washed wakame samples.

\section{Composting procedure}

To characterize the effects of the inoculation of strain HR6 and the different salinity content on the composting process, the wakame composting experiment was carried out in $500 \mathrm{ml}$ thermos bottles. The bacterium HR6 was first cultivated in modified LB (MLB) agar plates: $5 \mathrm{~g}$ Polypepton (Nihon Pharmaceutical Co. Ltd. Tokyo, Japan), 3 g Yeast extract (Nihon Pharmaceutical), $15 \mathrm{~g}$ agar in $1000 \mathrm{ml}$ distilled water, $\mathrm{pH}$ 7.5. Then it was inoculated into MLB liquid medium in test tubes and cultivated for 24 h. After that, the bacterium was inoculated at $0.5 \%$ into $100 \mathrm{ml}$ MLB liquid media in a $500 \mathrm{ml}$ triangle flask and cultivated under $30^{\circ} \mathrm{C}$ with shaking ( 120 rpm) for $24 \mathrm{~h}$. After centrifugation at $8,000 \mathrm{rpm}$ for 10 min at $4^{\circ} \mathrm{C}$, the cells were re-suspended in $50 \mathrm{ml}$ liquid medium and mixed with wakame. The final water content of the composting materials was adjusted to about $70 \%$. Then the inoculated wakame (about 200 g) was put into a $500 \mathrm{ml}$ stainless steel thermos bottle covered with cotton to keep heat loss and allow the aeration. Bottles for wakame composting were put in an incubator that was kept at constant temperature of $30^{\circ} \mathrm{C}$. The temperature inside the stainless steel bottle was recorded by Thermo Recorder TR$71 \mathrm{U}$ ( $\mathrm{T} \& \mathrm{D}$, Co. Ltd. Nagano, Japan). The composting material was weighed and mixed once everyday.

A large scale composting experiment was conducted in a $5 \mathrm{~L}$ container with insulation film outside to keep the temperature. Fig. 1 shows the diagram of

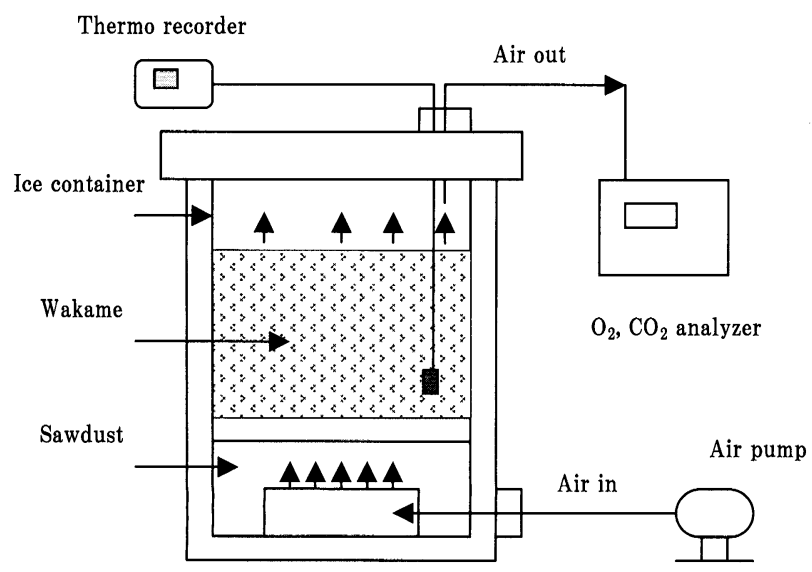

FIG. 1. Composting system of wakame in a $5 \mathrm{~L}$ container. the large scale composting system. Aeration was carried out by an air pump with flow rate of $0.5 \mathrm{~L} / \mathrm{min}$ from the bottom of the container. About $1.5 \mathrm{~kg}$ of wakame was used for the experiment with inoculation of strain HR6 from $500 \mathrm{ml}$ liquid media after $24 \mathrm{~h}$ of incubation at $30^{\circ} \mathrm{C}$. Changes in $\mathrm{O}_{2}$ and $\mathrm{CO}_{2}$ concentrations in the exhaust gas were analyzed by Exhaust Oxygen Carbon Dioxide Meter Model EX-1562-1 (Able \& Biott Co., Ltd. Tokyo, Japan). Samples were taken up appropriately after composting to analyze the changes of water content, $\mathrm{pH}$ and $\mathrm{C}$ as well as $\mathrm{N}$ contents during composting process. Changes in viable cell numbers were also traced during composting.

\section{Analyses}

The $\mathrm{pH}$ values and $\mathrm{NaCl}$ concentrations in the composting samples were analyzed after dilution of samples at a rate of $1: 9$ with distilled water and then measured by a $\mathrm{pH}$ meter ( $\mathrm{pH}$ Meter HM-20E, TOA Electronics Ltd. Tokyo, Japan) and HORIBA compact ion meter C-122 $\mathrm{NA}^{+}$(Horiba Ltd. Kyoto, Japan), respectively. The $\mathrm{NaCl}$ concentration was expressed as $\mathrm{NaCl}(\mathrm{mg}) / \mathrm{g}$ of wet wakame (abbreviated as $\mathrm{mg} / \mathrm{g}$ ). Water content in the samples was determined through the measurement of weight changes after drying the sample in an oven of $105^{\circ} \mathrm{C}$ for $24 \mathrm{~h}$. The dried samples were then ground to pieces of less than 50 meshes and $\mathrm{C}$ and $\mathrm{N}$ content were analyzed by NA 2100 Protein Nitrogen analyzer (ThermoQuest, Italia SPA. Milan, Italy).

The changes in the viable cell numbers were measured by the plate counting method. Samples of $1 \mathrm{~g}$ were put into $9 \mathrm{ml}$ sterilized water containing $0.5 \mathrm{M}$ $\mathrm{NaCl}$ and mixed thoroughly by an automatic lab mixer. After successive dilution, a $100 \mu$ I suspension was spread over the MLB agar plate and incubated under $30^{\circ} \mathrm{C}$. The colony forming units (CFU) were determined by counting them after 3 days of incubation. The strain HR6 was identified by colony shape, odor, and observation under microscope. In addition, the 16S rDNA sequence of HR6 strain was analyzed to confirm the existence of HR6 during the composting process.

The analysis of alginate content was based on the method introduced by Nishide et al. (1987) with some modification. Two $\mathrm{g}$ of a dry compost sample was first extracted with $100 \mathrm{ml}$ distilled water under stirring for $3 \mathrm{~h}$. After filtration through a layer of cloth, $50 \mathrm{ml}$ of $3 \% \mathrm{Na}_{2} \mathrm{CO}_{3}$ was added to the algal fronds and extraction was carried out at $75^{\circ} \mathrm{C}$ for $1 \mathrm{~h}$ under stirring. This process was repeated twice and the alginate solution was filtered through a layer of cloth. Then the alginate was precipitated and cleaned 
according to the procedure of Nishide et al. (1987). The alginate in the water and $\mathrm{Na}_{2} \mathrm{CO}_{3}$ solution was defined as water soluble alginate (WSA) and water insoluble alginate (WIA), respectively. Total alginate content (TA) was calculated based on the sum of WSA and WIA. The result was expressed as the percentage of the dry weight compost.

\section{S rDNA analysis of strain HR6}

Each single colony of the HR6 strain, which was picked up from plates incubated for $0 \mathrm{~h}$ or $24 \mathrm{~h}$, was suspended in $50 \mu \mathrm{L}$ of TE (10 mM Tris $\mathrm{HCl} ; \mathrm{pH} 7.5$, $1 \mathrm{mM}$ EDTA; pH 8.0) in microtubes and boiled at 100 ${ }^{\circ} \mathrm{C}$ for $10 \mathrm{~min}$. After incubation on ice for $5 \mathrm{~min}$ and centrifugation at $10,000 \times g$ for $5 \mathrm{~min}$, the supernatant was used as a template for polymerase chain reaction (PCR). The primers used to amplify the $16 S$ rDNA fragment were the 27F primer (5'-AGAGTTTG ATCCTGGCTCAG-3') (Hicks et al., 1992) and 516R primer (5'-TTACCGCGGCTGCTGGCA-3') (Fredricks and Rehman, 1998). Sequencing was performed with an ABI PRISM TM Dye Terminator Cycle Ready Reaction Kit (Applied Biosystems Inc., USA) using ABI PRISM3100 Genetic Analyzer (Applied Biosystems Inc., USA).

\section{RESULTS AND DISCUSSION}

\section{Effect of strain HR6 inoculation in wakame com- posting}

Fig. 2 shows the change in temperature during the composting of wakame by strain HR6 in a thermos bottle under different conditions. The temperature began to increase after $8 \mathrm{~h}$ of incubation and reached the maximum of $54.9-55.7^{\circ} \mathrm{C}$ after $18-20 \mathrm{~h}$ of incubation when HR6 was inoculated in the wakame (Run2, Run3, Run4), although in the control (Run1) the temperature did not change. The addition of skim milk (Run3) and autoclave treatment of wakame (Run4) showed no difference in temperature change as compared with that of Run2 with only the addition of HR6. The difference in temperature change suggested that inoculation of strain HR6 in wakame had greatly accelerated the composting activity. The effect of inoculation on the composting process was also found in other composting processes (Ichida et al., 2001; Bolta et al., 2003; Chang et al., 2006; Xi et al., 2005). The activity of strain HR6 was not affected by the autoclave treatment of wakame or the addition of nutrients, which indicates that strain HR6 can be generally applied for inoculation in wakame composting.

\section{Effect of salinity on the composting of wakame}

Effect of salinity on the composting of wakame by

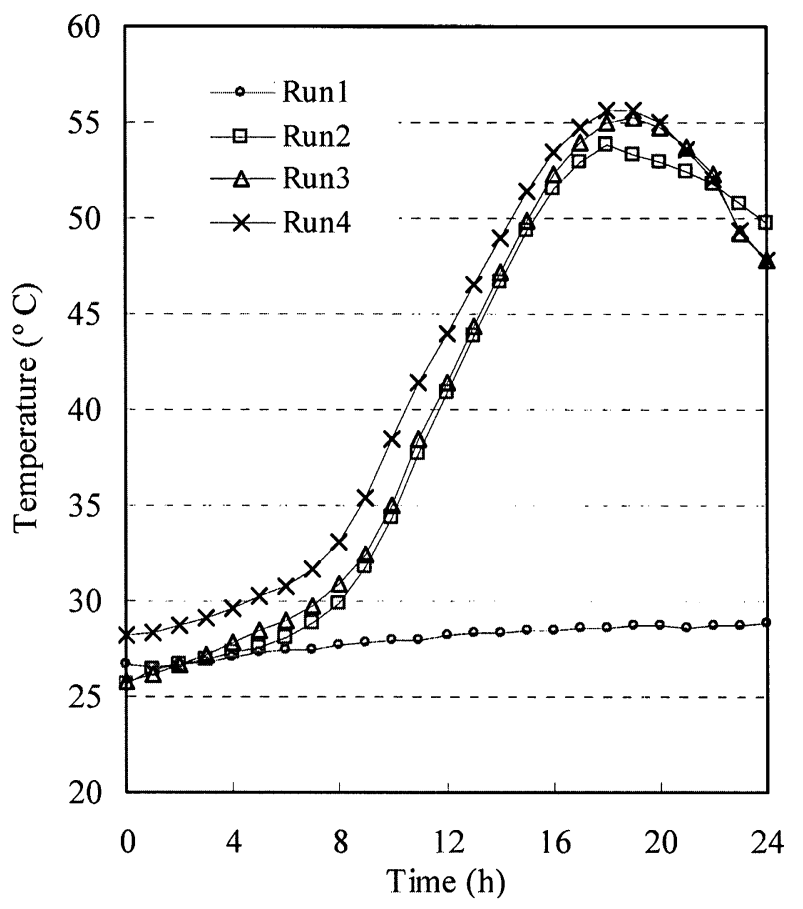

FIG. 2. Temperature changes during the wakame composting process by inoculation of strain HR6. The experiment was conducted in thermos bottles under different conditions as follows; Run 1, only wakame with moisture adjusted to about $70 \%$ was used as control; Run2, wakame was mixed with strain HR6; Run3, wakame was added with $5 \mathrm{~g}$ skim milk and mixed with HR6; Run4, wakame was first autoclaved and then mixed with HR6.

inoculating strain HR6 was carried out by mixing the dried wakame and washed wakame at different ratios of $0,20,50$ and $80 \%$, which led to $\mathrm{NaCl}$ concentrations of $15.2,18.7,23.6$, and $28.2 \mathrm{mg} / \mathrm{g}$, respectively. As shown in Fig. 3, the initiation of the increase in temperature was delayed by $\mathrm{NaCl}$ in proportion to its concentrations in wakame samples. The time needed to reach the maximum temperature was also different with $19,25,35$ and $40 \mathrm{~h}$ in the composting processes with $\mathrm{NaCl}$ content of 15.2, 18.7, 23.6 and $28.2 \mathrm{mg} / \mathrm{g}$, respectively, indicating a shorter lag time with lower salinity. Maximum temperatures were $53-55^{\circ} \mathrm{C}$ in the presence of $15.2,18.7$ and $23.6 \mathrm{mg} / \mathrm{g}$ of $\mathrm{NaCl}$, while a lower maximum temperature of about $48^{\circ} \mathrm{C}$ was found at the $\mathrm{NaCl}$ content of $28.2 \mathrm{mg} / \mathrm{g}$. The reduction of wet weight at 24 and $48 \mathrm{~h}$ of incubations was the highest in the presence of $15.2 \mathrm{mg} / \mathrm{g} \mathrm{NaCl}$ among the samples examined (Table 2). In the samples with $15.2-23.6 \mathrm{mg} / \mathrm{g} \mathrm{NaCl}$ content, however, there was not so much difference, although $28.2 \mathrm{mg} / \mathrm{g} \mathrm{NaCl}$ sample showed poor reduction of the wet weight. The result proved that composting can be conducted even when the $\mathrm{NaCl}$ content is as high as $28.2 \mathrm{mg} / \mathrm{g}$ with the inoculation of HR6, although lower salinity is better for 
the initiation and activity of composting process. This is important for the field treatment of wakame when the salinity content is high. In addition, the salinity of $15.2 \mathrm{mg} / \mathrm{g}$ is also relatively high compared to that of common composting materials, suggesting that HR6 is superior for the disposal of waste with high salinity. The presence of $\mathrm{Na}^{+}$sometimes may stimulate the decomposition activity of some components in wakame. For example alginate in wakame is degraded in the form of Na-alginate (Moen et al.,

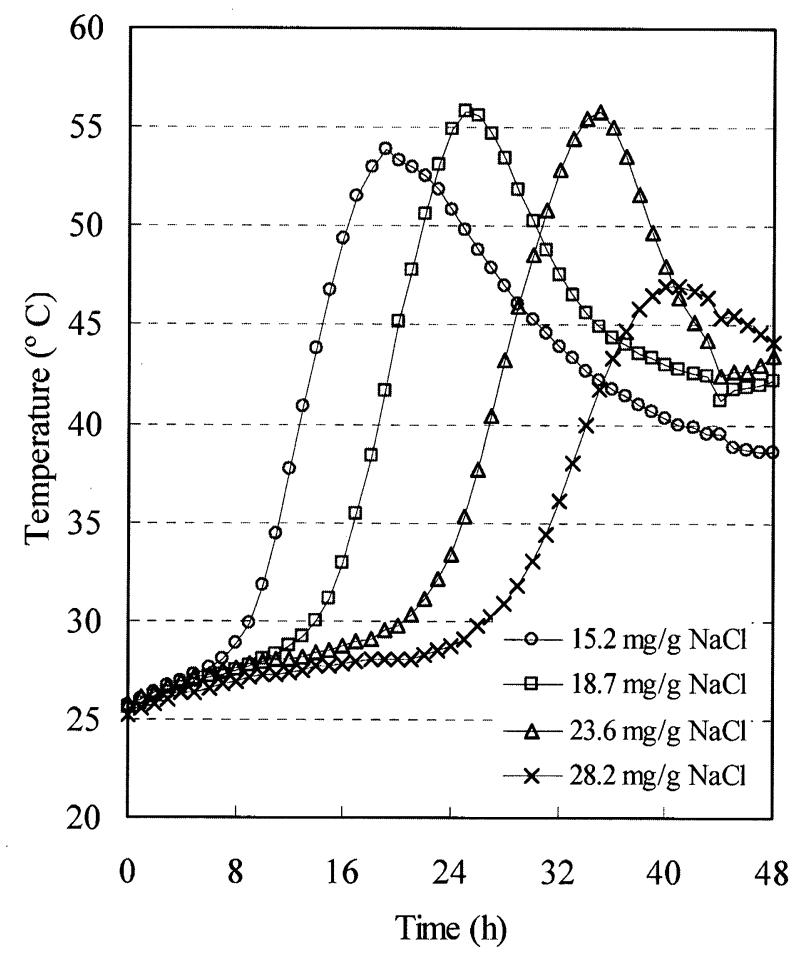

FIG. 3. Effect of salinity on the temperature changes during the wakame composting process by inoculation of strain HR6. Different salinity was obtained by mixing the dried wakame and washed wakame at different ratios 0 , 20,50 and $80 \%$, which led to $\mathrm{NaCl}$ concentrations of 15.2 , $18.7,23.6$, and $28.2 \mathrm{mg} / \mathrm{g}$, respectively. The moisture content was adjusted to around $70 \%$ and composting experiment was conducted in $500 \mathrm{ml}$ thermos bottles. 1997a), but the Ca-crosslinked alginate matrix of brown seaweeds may present a limiting factor when microbes decompose algal tissue (Moen and Ostgaard, 1997b). The proper level of salinity may be required for the composting disposal of wakame.

\section{Physico-chemical and microbial changes in a large scale composting}

Changes in the temperature, $\mathrm{O}_{2}$ and $\mathrm{CO}_{2}$ in exhaust gas were examined in a large scale process by inoculating strain HR6. During $100 \mathrm{~h}$ of incubation, two peaks were found in temperature changes: one was a sharp change in the initial period at $19 \mathrm{~h}$ and the other a broad change in the late period at around $60 \mathrm{~h}$, as shown in Fig. 4. The temperature changes corresponded to the changes in $\mathrm{O}_{2}$ and $\mathrm{CO}_{2}$ contents al-

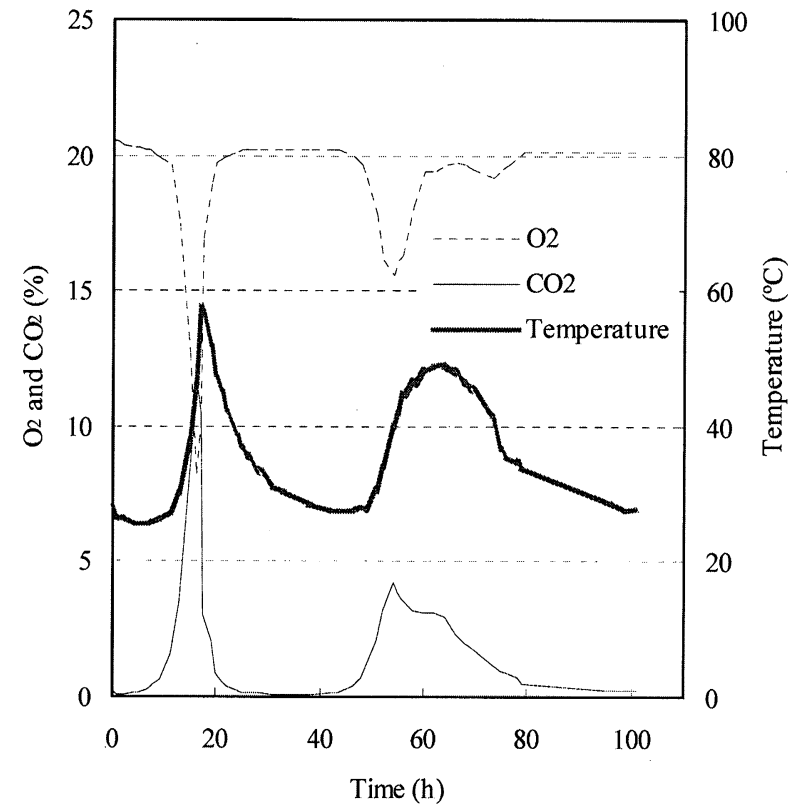

FIG. 4. Changes in $\mathrm{O}_{2}, \mathrm{CO}_{2}$ and temperature during a large scale composting process by inoculation of strain HR6. Temperature was detected by thermo recorder in the center part of the composting material. The $\mathrm{O}_{2}$ and $\mathrm{CO}_{2}$ content in the air around was $21 \%$ and $0 \%$, respectively.

TABLE 2. Relative changes of wet weight during the composting of wakame with the inoculation of strain HR6 under different salinity conditions

\begin{tabular}{ccccc}
\hline Incubation & \multicolumn{4}{c}{ Wet weight (\%) } \\
\cline { 2 - 5 } time $(h)$ & $15.2 \mathrm{mg} / \mathrm{g} \mathrm{NaCl}$ & $18.7 \mathrm{mg} / \mathrm{g} \mathrm{NaCl}$ & $23.6 \mathrm{mg} / \mathrm{g} \mathrm{NaCl}$ & $28.2 \mathrm{mg} / \mathrm{g} \mathrm{NaCl}$ \\
\hline 0 & 100.0 & 100.0 & 100.0 & 100.0 \\
24 & 98.7 & 99.2 & 99.2 & 99.6 \\
48 & 97.2 & 97.4 & 97.6 & 98.5 \\
\hline
\end{tabular}

The different $\mathrm{NaCl}$ contents were obtained by mixing the dried wakame and washed wakame at different ratios and then adjusting the water content to a proper level. The composting was conducted in the thermos bottle and weight change was then analyzed. 
though a lag time of about $2 \mathrm{~h}$ was found for temperature changes compared to the changes in $\mathrm{O}_{2}$ and $\mathrm{CO}_{2}$. This means that the temperature change is the

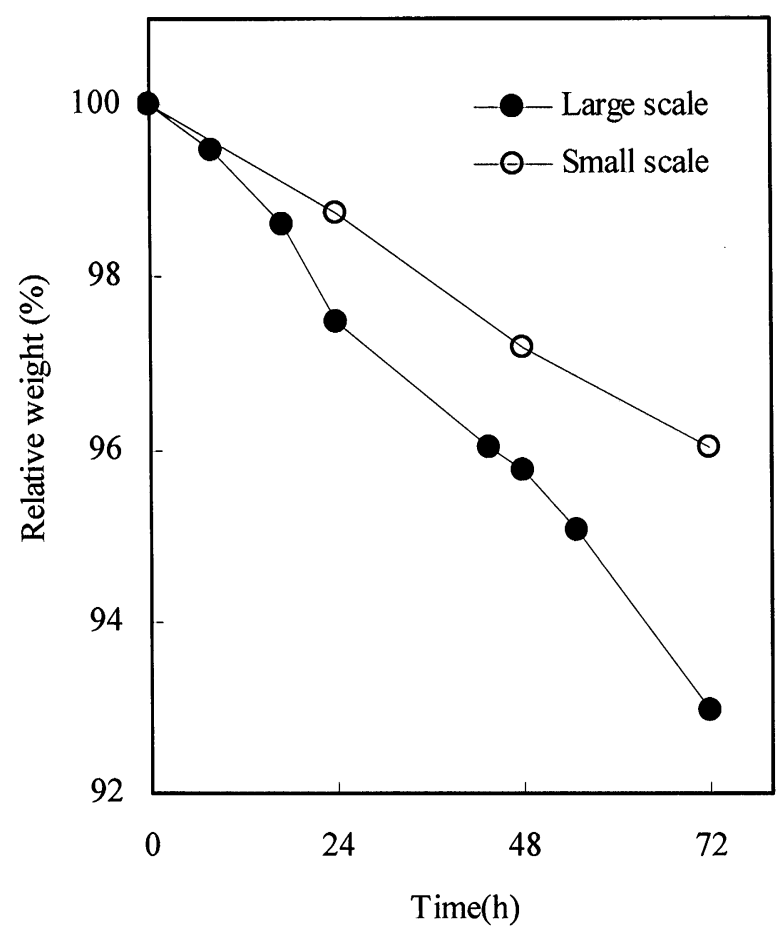

FIG. 5. Changes in the relative weight during the composting process by inoculation of strain HR6 in large and small scale experiments. Both composting processes used the same materials for composting. result of cellular respiration. An attempt was made to examine whether the scale of bottles affected changes of wet weight or not. The decreasing rate of wet weight is higher in the large scale composting process compared to that in the small scale because the moisture can be taken out through the exhaust gas (Fig. 5). Wet weight also showed a higher decrease value during the composting period when both $\mathrm{O}_{2}$ consumption and $\mathrm{CO}_{2}$ emission were high. Next, the reduction rate of organic materials was also traced, which was $93.4 \%$ after $72 \mathrm{~h}$ of composting (Table 3). The value was not so high probably due to the short composting time and high content of not easily degradable substances in the wakame. However, the appearance of the wakame compost changed greatly, with a change in color from light green to brown-black and the materials became muddy-like. The $\mathrm{pH}$ increased to 8.83 after $72 \mathrm{~h}$ of incubation from the initial value of 7.41. Initial $\mathrm{N}$ and $\mathrm{C}$ contents were $3.9 \%$ and $34.0 \%$, respectively, which decreased during the composting process. Nitrogen content in the present compost was relatively high compared to other kinds of compost as the $\mathrm{N}$ content in most compost products falls to less than $4 \%$ (Tang et al., 2003). The initial $\mathrm{C} / \mathrm{N}$ ratio, 8.8 , increased to 10.1 after $72 \mathrm{~h}$ of incubation. The $\mathrm{C} / \mathrm{N}$ ratio in this study was lower than common initial $\mathrm{C} / \mathrm{N}$ ratios which are higher than 15 (Bernal et al., 1998).

The changes in viable cell numbers of strain HR6 and total bacteria were followed during $72 \mathrm{~h}$ of incu-

TABLE 3. Changes in chemical properties during wakame composting by inoculation of strain HR6 in a large scale process

\begin{tabular}{cccccc}
\hline $\begin{array}{c}\text { Incubation } \\
\text { time (h) }\end{array}$ & Dry weight (\%) & $\mathrm{pH}$ & $\mathrm{N}(\%)$ & $\mathrm{C}(\%)$ & $\mathrm{C} / \mathrm{N}$ \\
\hline 0 & 100 & 7.41 & 3.9 & 34.0 & 8.8 \\
24 & 97.1 & 7.96 & - & - & - \\
48 & 96.1 & 8.43 & - & - & - \\
72 & 93.4 & 8.83 & 3.2 & 32.4 & 10.1 \\
\hline
\end{tabular}

The large scale experiment was conducted with aeration and samples were taken at different times to check $\mathrm{pH}$ values as well as $\mathrm{C}$ and $\mathrm{N}$ contents

TABLE 4. Changes in the viable cell numbers of strain HR6 and total bacteria during a large scale composting process by inoculation of strain HR6

\begin{tabular}{cccccccc}
\hline & \multicolumn{7}{c}{ Viable cell numbers $\left(\times 10^{8} \mathrm{CFU} / \mathrm{g}\right)$} \\
\cline { 2 - 7 } Bacteria & \multicolumn{7}{c}{ Time $(\mathrm{h})$} \\
\cline { 2 - 7 } & 0 & 18 & 24 & 48 & 55 & 72 \\
\hline HR6 & $1.10 \pm 0.17$ & $2.75 \pm 0.07$ & $8.60 \pm 0.42$ & $1.20 \pm 0.56$ & $0.40 \pm 0.28$ & $0.10 \pm 0.00$ & $0.30 \pm 0.14$ \\
Total & $1.10 \pm 0.17$ & $2.75 \pm 0.07$ & $8.60 \pm 0.42$ & $1.20 \pm 0.56$ & $18.50 \pm 4.95$ & $183.00 \pm 24.04$ & $6.50 \pm 0.42$ \\
\hline
\end{tabular}

The viable cell numbers were enumerated by diluting the samples to proper level and swabbing the samples on agar plates. Strain HR6 was identified by colony shape and observation under microscope. In addition, the 16S rDNA sequence of HR6 strain was analyzed to confirm the existence of HR6 during the composting process. 
bation as shown in Table 4. The initial cell numbers of strain HR6 inoculated were $1.1 \times 10^{8} \mathrm{CFU} / \mathrm{g}$, which increased within $24 \mathrm{~h}$ of the composting process and then decreased gradually. The partial $16 S$ rDNA sequence of isolated strain after the $24 \mathrm{~h}$ of composting showed $100 \%$ similarity with that of $\mathrm{Oh}$ and $B$. subtilis (Accession No. AB110598), which confirms that the inoculated HR6 belongs to strain B. subtilis and may proliferate during composting of wakame. A sharp increase in total bacterial numbers was found at $55 \mathrm{~h}$ of incubation, $1.83 \times 10^{10} \mathrm{CFU} / \mathrm{g}$, which was much higher than the initial value. After 3 days of composting, the total viable cell numbers decreased to the level of $6.5 \times 10^{8} \mathrm{CFU} / \mathrm{g}$. The numbers of strain HR6 were equal to the total count within $24 \mathrm{~h}$ and then decreased. The present results suggested that strain HR6 was predominant before $24 \mathrm{~h}$ of incubation and then other microorganisms proliferated during the following period of composting. The viable cell numbers are similar with those in the manure composting process, varying from $4.2 \times 10^{8}$ to $1.7 \times 10^{10}$ CFU/g (Vuorinen et al. 1999), but smaller when compared to those of other composting processes such as food garbage composting (Hiraishi et al. 2000). We also found that the booming growth of bacteria at $55 \mathrm{~h}$ of incubation was caused by other unknown bacteria but not strain HR6 from the shape and color of the colonies on the agar plates. The microbial community of wakame compost also consisted of a diverse microbial species after $48 \mathrm{~h}$ of composting. The results suggested that strain $\mathrm{HR} 6$ is effective in the initial period of wakame composting and other microorganisms natively present in the wakame may also proliferate during the composting process. The microbial community also became complex with the succession of incubation time in a common manure composting process as detected by the quinone profile method (Tang et al. 2004).

The changes in different types of alginate are shown in Table 5, which shows that TA was $32.2 \%$ at the beginning, most of which was water insoluble alginate (WIA). The TA value increased after $24 \mathrm{~h}$, which can be explained to be caused by the decomposition of easily decomposable substances such as protein or saccharides by HR6 in the initial period of

TABLE 5. Change in different types of alginate during the composting process

\begin{tabular}{rcccc}
\hline Time & WSA(\%) & WIA(\%) & WSA/WIA & TA(\%) \\
\hline $0 \mathrm{~h}$ & 2.9 & 29.3 & 0.10 & 32.2 \\
$24 \mathrm{~h}$ & 3.6 & 30.1 & 0.12 & 33.6 \\
$72 \mathrm{~h}$ & 4.4 & 24.8 & 0.18 & 29.2 \\
\hline
\end{tabular}

TA : Total content of alginate, WSA : Water soluble alginate, WIA: Water insoluble alginate composting. The TA value then decreased to $29.2 \%$ after $72 \mathrm{~h}$ of composting, which corresponded to the second peak of temperature and respiration changes. WIA showed a similar tendency as that of TA, while WSA increased until $72 \mathrm{~h}$ of composting, suggesting that alginate inside the cells of wakame or combined with $\mathrm{Ca}^{2+}$ was gradually dissolved to sodium alginate during composting process. We also found that the ratio of WSA/WIA increased during the composting process, indicating the occurrence of solubilization and decomposition of wakame during the composting process.

The result shown above might suggest that around the second peak of temperature increase, $\mathrm{O}_{2}$ consumption or $\mathrm{CO}_{2}$ generation had contributed to the decomposition of alginate during this period. The total bacterial numbers also increased and the microbial community consisted of mixed strains of bacteria including HR6. Thus, we conclude that the bacteria increasing around $55 \mathrm{~h}$ could be attributed to the following composting of wakame waste, especially the decomposition of alginate. A complex microbial community may be important and effective for the decomposition of wakame during this period of time. However, HR6 played an important role in the initial period of composting and that the inoculation of HR6 shortened the time to establish a complex microbial community for further decomposition of wakame waste as decomposition of wakame by HR6 may facilitate the growth of other microorganisms.

\section{REFERENCES}

Bernal, M.P., Paredes, C., Sanchez-Monedero, M.A., and Cegarra, J. (1998) Maturity and stability parameters of composts prepared with a wide range of organic wastes. Bioresource Technol., 63, 91-99.

Bolta, S.V., Mihelic, Lobnik, R., F., and Lestan, D. (2003) Microbial community structure during composting with and without mass inocula. Compost Sci. Util., 11, 6-15.

Campbell, S.J., Bite, J.S., and Burridge, T.R. (1999) Seasonal patterns in the photosynthetic capacity, tissue pigment and nutrient content of different developmental stages of Undaria pinnatifida (Phaeophyta: Laminariales) in Port Phillip Bay south-eastern Australia. Bot. Mar., 42 , 231-241.

Chang, J.I., Tsai, J.J., and Wu, K.H. (2006) Thermophilic composting of food waste. Bioresource Technol., 97, 116-122.

Eyras, M.C., Rostagno, C.M., and Defosse, G.E. (1998) Biological evaluation of seaweed composting. Compost Sci. Util., 6, 74-81.

Fredricks, D.N, and I Relman D.A. (1998) Improved amplification of microbial DNA from blood cultures by removal of the PCR inhibitor sodium polyanetholesulfonate. J. Clin. Microbiol., 36, 2810-2816.

Hicks, R.E., Amann, R.I., and Stahl, D.A. (1992) Dual staining of natural bacterial plankton with 4,,6-diamidino-2 
phenylindole and fluorescent oligonucleotide probes targeting kingdom-level 16S rRNA sequences. Appl. Environ. Microbiol., 58, 2158-2163.

Hiraishi, A., Yamanaka, Y., and Narihiro, T. (2000) Seasonal microbial community dynamics in a flowerpotusing personal composting system for disposal of household biowaste. J. Gen. Appl. Microbiol., 46, 133-146.

Ichida, J.M., Krizova, L., LeFevre, C.A., Keener, H.M., Elwell, D.L., and Burtt, E.H. (2001) Bacterial inoculum enhances keratin degradation and biofilm formation in poultry compost. J. Microbiol. Meth., 47, 199-208.

Maeda, K., Mimura, H., and Nagata, S. (2003) Microbial degradation of solid and suspended organic substances of Blue Mussels obtained after compression treatment by Bacillus sp. HR6 (in Japanese). Kankyo Gijyutsu, 32, 738-746.

Mimura, H., Maeda, S. Higashi, T., and Nagata, S. (1995) Biological decomposition of food wastes by Bacillus sp. HR6 (in Japanese). Kankyo Gijyutsu, 24, 513-516.

Mimura, H., Maeda, K., and Nagata, S. (1999a) Chromatographic analysis of bean curd refuse decomposed by Bacillus sp. HR6. Biocontrol Sci., 4, 23-26.

Mimura, H., and Nagata, S. (1999b) Physiological characteristics of Bacillus sp. HR6 in the process of decomposing bean curd refuse. Biocontrol Sci., 4, 105-108.

Moen, E., Horn, S., and Ostgaard, K. (1997a) Alginate degradation during anaerobic digestion of Laminaria hyperborea stipes. J. Appl. Phycol., 9, 157-166.

Moen, E., and K. Ostgaard. (1997b) Aerobic digestion of Ca-alginate gels studied as a model system of seaweed tissue degradation. J. Appl. Phycol., 9, 261-267.

Nishide, E, Anzai, H., and Uchida, N. (1987) Extration of alginic acid from a Brazillian brown alga, Laminaria brasiliensis. Hydrobiologia, 151/152, 551-555.

Skriptsova, A., Khomenko, V., and Isakov, V. (2004) Seasonal changes in growth rate, morphology and alginate content in Undaria pinnatifida at the northern limit in the Sea of Japan (Russia). J. Appl. Phycol., 16, 17-21.

Tang, J.C., Inoue, Y., Yasuta, T., Yoshida, S., and Katayama, A. (2003) Chemical and microbial properties of various compost products. Soil Sci. Plant Nutr., 49, 273-280.

Tang, J.C., Kanamori, T., Inoue, Y., Yasuta, T., Yoshida, S., and Katayama, A. (2004) Changes in microbial community structure in thermophilic composting process of manure detected by quinone profile method. Process Biochem., 39, 1999-2006.

Torres, A.I., Gil, M.N., and Esteves, J.L. (2004) Nutrient uptake rates by the alien alga Undaria pinnatifida (Phaeophyta) (Nuevo Gulf, Patagonia, Argentina) when exposed to diluted sewage effluent. Hydrobiologia, 520, 1-6.

Vendrame, W., and Moore, K.K. (2005) Comparison of herbaceous perennial plant growth in seaweed compost and biosolids compost. Compost Sci. Util., 13, 122-126.

Vuorinen, A.H., and Saharinen, M.H. (1999) Cattle and pig manure and feat composting in a drum composting system: Microbiological and chemical parameters. Compost Sci. Util., 7, 54-65.

Xi, B.D., Zhang, G.J., and Liu, H.L. (2005) Process kinetics of inoculation composting of municipal solid waste. J. Hazard. Mater., 124, 165-172.

Yamada, N. (2001) The Science of seaweed utilization (in Japanese), Seizando Press, Tokyo, Japan. 